\title{
Relevance of the ancestry for the variability of the Drug-Metabolizing Enzymes CYP2C9, CYP2C19 and CYP2D6 polymorphisms in a multiethnic Costa Rican population
}

\author{
Carolina Céspedes-Garro ${ }^{1,2 \dagger}$, Fernanda Rodrigues-Soares ${ }^{3 \dagger}$, Gerardo Jiménez-Arce ${ }^{2}$, \\ María-Eugenia G. Naranjo ${ }^{1}$, Eduardo Tarazona-Santos ${ }^{3,4}$, Humberto Fariñas ${ }^{1}$, Ramiro \\ Barrantes $^{2 *}$, Adrián Llerena ${ }^{1} \&$ CEIBA.FP Consortium of the Ibero-American Network of \\ Pharmacogenetics \& Pharmacogenomics RIBEF ${ }^{\mathrm{a}}$ \\ 1. CICAB Clinical Research Center, Extremadura University Hospital and Medical School, 06080 Badajoz, \\ Spain; carolina.cespedesgarro@ucr.ac.cr, megonzalezn@unex.es, humberto.farinas@ses.juntaextremadura.net, \\ allerena@unex.es \\ 2. Genetics Section, School of Biology, University of Costa Rica, 2060 San Pedro, San José, Costa Rica; \\ carolina.cespedesgarro@ucr.ac.cr, gerardo.jimenez@ucr.ac.cr, ramiro.barrantes@ucr.ac.cr \\ 3. Departamento de Biologia Geral. Universidade Federal de Minas Gerais, 31270-901 Belo Horizonte, Brazil; \\ fernandasoares@ufmg.br, edutars@icb.ufmg.br \\ 4. Asociación Benéfica PRISMA, Lima 32, Lima, Perú; edutars@icb.ufmg.br \\ $\dagger$ Co-first authorship $* *$ Correspondence
}

Received 18-IX-2015. C Corrected 08-II-2016. Accepted 09-III-2016.

\begin{abstract}
CYP2C9, CYP2C19 and CYP2D6 metabolize around $40 \%$ of drugs and their genes vary across populations. The Costa Rican population has a trihybrid ancestry and its key geographic location turns it into a suitable scenario to evaluate interethnic differences across populations. This study aims to describe the diversity of CYP2C9, CYP2C19 and CYP2D6 polymorphisms in Costa Rican populations in the context of their ancestry. A total of 448 healthy individuals were included in the study: Bribri $(n=47)$, Cabécar $(n=27)$, Maleku $(n=16)$, Guaymí $(n=30)$, Huetar $(n=48)$, Chorotega $(n=41)$, Admixed/Mestizos from the Central Valley/Guanacaste $(\mathrm{n}=189)$, and Afro-Caribbeans $(\mathrm{n}=50)$ from Limón. CYP2C9 (alleles *2, *3, *6) and CYP2C19 $(* 2, * 3, * 4$, $* 5, * 17)$ genotypes were determined by Real-Time PCR. African, European and Native American ancestry were inferred using 87 ancestry informative markers. The frequency of the decreased activity allele $C Y P 2 C 9 * 2$ is lower in the self-reported Amerindian groups compared to the admixed population, and the highest frequencies of $C Y P 2 C 19 * 2$ (null activity) and the CYP $2 C 19 * 17$ (increased activity) were found in the self-reported AfroCaribbean population. Moreover, a frequency of $0.7 \% C Y P 2 C 9 \mathrm{gPMs}$ in the Admixed population and a variable frequency of CYP2C19 gUMs (0.0-32.6\%, more prevalent in Afro-Caribbeans) in Costa Rican populations, was found. Finally, the following alleles were positively correlated with genomic African ancestry and negatively correlated with genomic Native American ancestry: CYP2D6*5 (null activity), CYP2D6*17 (decreased activity), CYP2D6*29 (decreased activity) and CYP2C19*17 (increased activity). No correlation for CYP2C9 polymorphisms and genomic ancestry was found. Further studies assessing the $C Y P 2 C 9$ and $C Y P 2 C 19$ sequence in these populations, preferentially by sequencing these genes, are warranted. Rev. Biol. Trop. 64 (3): 1067-1076. Epub 2016 September 01.
\end{abstract}

Key words: $C Y P 2 C 9, C Y P 2 C 19 ; C Y P 2 D 6$, Costa Rica, Amerindian, Afro-Caribbean, genomic ancestry.

${ }^{a}$ CEIBA Consortium of authors (*group coordinator):

Group 1 Authors: Graciela E. Moya*, Verónica Ferreiro. Institutions: Pontificia Universidad Católica, Buenos Aires, Argentina; Argentina \& Fundación GENOS, Buenos Aires, Argentina. 
Cytochrome P450 enzymes (CYPs) are involved in the phase I metabolism of endobiotics and xenobiotics (i.e. drugs). Thus, the activity of these enzymes is related to the plasmatic levels of active drug in patients, as well as to their therapeutic effect. In the CYP2C subfamily of drug-metabolizing enzymes (DMEs), CYP2C9 and CYP2C19 are encoded by the $C Y P 2 C$ gene cluster in $10 \mathrm{q} 24$, and are polymorphic, presenting interethnic variability (CYP2C19 allele nomenclature, 2015; Sistonen et al., 2009).

CYP2C9 is involved in the metabolism of drugs such as warfarin, losartan, fluoxetine and non-steroidal anti-inflammatory drugs. Around 60 CYP2C9 gene variants have been described (CYP2C9 allele nomenclature, 2015), which explain a considerable proportion of variability in the drug metabolism. Some CYP $2 C 9$ alleles have been related to a null or decreased hydroxylation capacity, such as CYP $2 C 9 * 3$ allele that dramatically reduces the enzyme activity (Ingelman-Sundberg, Sim, Gomez, \& Rodriguez-Antona, 2007). Thus, the carriers of two $C Y P 2 C 9 * 3$, as well as, alleles with null capacity are predicted to be poor metabolizers (gPMs) and to suffer adverse drug reactions (ADRs) (Yang et al., 2013).

CYP2C19 is responsible for the metabolism of antidepressants and proton pump inhibitors, among other drugs. A total of 34 CYP2C19 allelic variants that affect enzyme activity have been described, from null (i.e. $C Y P 2 C 19 * 2, * 3, * 4, * 5)$ to increased activity (i.e. CYP2C19*17) (CYP2C19 allele nomenclature, 2015). Individuals carriers of two inactive CYP2C19 alleles are predicted to be gPMs, while carriers of $* 1 / * 17$ or $* 17 / * 17$ genotypes are predicted ultrarapid metabolizers (gUMs). In pharmacological treatment, ADRs for both metabolic groups have been shown. Drug Regulatory Agencies report CYP2C19 as a pharmacogenetic biomarker for 16 drugs (Center for Drug Evaluation and Research, 2015) and that CYP2C19 status of patients might predict clinical outcomes (Altar et al., 2015; Niu et al., 2015; Tabata et al., 2015).

Group 2 Authors: Eduardo Tarazona-Santos*, Fernanda Rodrigues-Soares. Institution: Universidade Federal de Minas Gerais, Belo Horizonte, Brasil.

Group 3 Authors: Alba P. Sarmiento*, Angélica Borbón. Institution: (previous) Pontificia Universidad Javeriana, Bogotá, Colombia.

Group 4 Authors: Ramiro Barrantes*, Gerardo Jiménez-Arce, Carolina Céspedes-Garro. Institution: Universidad de Costa Rica, San José, Costa Rica.

Group 5 Authors: Idania Rodeiro ${ }^{1 *}$, Mayra Álvárez², René Delgado ${ }^{3}$, Diadelis Remirez ${ }^{4}$, Bárbaro Pérez², Luis R. Calzadilla ${ }^{5 *}$. Institutions: ${ }^{1} \mathrm{CEBIMAR} ;{ }^{2} \mathrm{Facultad}$ de Medicina Calixto García; ${ }^{3} \mathrm{CIDEM} ;{ }^{4} \mathrm{CECMED},{ }^{5}$ Centro Comunitario de Salud Mental La Habana Vieja, La Habana, Cuba.

Group 6 Authors: Enrique Terán ${ }^{1 *}$, Santiago Terán ${ }^{1}$, Francisco Hernández ${ }^{2}$. Institutions: ${ }^{1}$ Universidad San Francisco de Quito, Quito, Ecuador, ${ }^{2}$ Universidad Estatal de Guayaquil, Guayaquil, Ecuador.

Group 7 Authors: Rocío Ortiz-López*, Augusto Rojas-Martínez, Lourdes Garza-Ocañas, Yadira X. Pérez-Páramo. Institution: Universidad Autónoma de Nuevo León, Monterrey, Nuevo León, México.

Group 8 Authors: Marisol López-López*, Alberto Ortega-Vázquez, Nancy Monroy-Jaramillo, Helgi Jung-Cook, Ingrid Fricke-Galindo, Elisa Alonso-Vilatela, Teresa Corona-Vázquez. Institutions: Universidad Autónoma Metropolitana \& Instituto Nacional de Neurología y Neurocirugía Manuel Velasco Suárez, México City, México.

Group 9 Authors: Martha G. Sosa-Macías*, Carlos Galaviz-Hernández, Ismael Lares-Aseff, Blanca P. Lazalde-Ramos. Institution: Instituto Politécnico Nacional-CIIDIR, Durango, México.

Group 10 Author: Ronald Ramírez-Roa*, Catalina Altamirano Tinoco. Institution: Universidad Nacional Autónoma de Nicaragua, León, Nicaragua.

Group 11 Author: Manuela Grazina*. Institution: University of Coimbra, Coimbra, Portugal.

Group 12 Authors: Adrián Llerena*, Pedro Dorado, Eva M. Peñas-Lledó, Jesús Cobaleda, M. Eugenia G. Naranjo, Fernando de Andrés, Humberto Fariñas. Institution: University of Extremadura, Badajoz, Spain.

Group 13 Author: Francisco E. Estévez-Carrizo*. Institution: Universidad de Montevideo, Montevideo, Uruguay. 
CYP2D6 metabolizes a wide range of drugs such as antidepressants, antiarrythmics, antipsychotics, and antihistamines. More than 100 allelic variants have been described for this gene, some of which have been related to null, decreased, normal and increased enzyme activity (CYP2D6 allele nomenclature, 2015). CYP2D6 gPMs and gUMs have been related to clinical outcomes in pharmacological therapy (Rolla et al., 2014; Seripa et al., 2015; Youngster et al., 2014) and Drug Regulatory Agencies report CYP2D6 as a pharmacogenetic biomarker for forty drugs (Center for Drug Evaluation and Research, 2015).

Interethnic differences in such cytochrome P450 genetic polymorphisms are partially responsible for the variations among populations in drug disposition. The trihybrid ancestry of the Costa Rican population (Segura-Wang, Raventós, Escamilla, \& Barrantes, 2010), and the key geographic location of the country makes Costa Ricans fairly representative of the human genetic diversity in Central America.

The CEIBA.FP Consortium of the IberoAmerican Network of Pharmacogenetics \& Pharmacogenomics (RIBEF) has carried out studies in different Latin American populations (Dorado et al., 2012a; Dorado, Gallego, PeñasLledó, Terán, \& Llerena, 2014), contributing to increase the pharmacogenetic knowledge of these neglected populations. Nevertheless, this is the first report of the CYP2C subfamily in a Costa Rican population including groups from different ethnic backgrounds. The present study aims to estimate the allele frequencies of CYP2C9, CYP2C19 and CYP2D6 polymorphisms in Costa Rican populations with different ancestry backgrounds.

\section{MATERIALS AND METHODS}

Subjects: The study comprised 448 healthy individuals, of which 385 were previously studied for the CYP2D6 gene (Céspedes-Garro, Jiménez-Arce, Naranjo, Barrantes, \& Llerena, 2014). The following Native American Chibchan populations were analyzed: Bribri $(\mathrm{n}=$ 47), Cabécar ( $n=27)$, Maleku ( $n=16)$, Guaymí $(n=30)$ and Huetar $(n=48)$. An Oto-Manguean Mesoamerican Amerindian group: Chorotega $(n=41)$ was also included. Moreover, Admixed/Mestizos from the Central Valley and Guanacaste $(n=189)$, and Afro-Caribbeans $(n=50)$ from Limón were included (CéspedesGarro et al., 2014a). The number of analyzed subjects varied according to the $C Y P 2 C$ gene and genomic ancestry analyses (Table 1, Table 2 and Table 3 ).

All DNA samples were obtained from a DNA biobank of the School of Biology of the University of Costa Rica. The samples were collected and stored after approval from review boards of the University of Costa Rica. Further information of collection and demographic data is available elsewhere (Azofeifa et al., 2004; Barrantes et al., 1990; Barrantes, Smouse, Neel, Mohrenweiser, \& Gershowitz, 1982). The inclusion criteria of individuals in each group were previously defined (CéspedesGarro et al., 2014a).

Methods: The strategy followed in the study has been designed by the CEIBA-MESTIFAR Project (Sosa-Macias et al., 2015).

Genomic ancestry: A total of 87 ancestry informative markers (AIMs) selected from

TABLE 1

Mean of the genomic ancestry for different Costa Rican ethnic groups

\begin{tabular}{lcccc}
\multicolumn{1}{r}{ Population } & $\mathrm{n}$ & European ancestry & African ancestry & Native American ancestry \\
Admixed & 32 & 0.429 & 0.168 & 0.403 \\
Bribri & 12 & 0.182 & 0.072 & 0.745 \\
Chorotega & 26 & 0.220 & 0.090 & 0.690 \\
Guaymí & 18 & 0.030 & 0.027 & 0.943 \\
Afro-Caribbean & 11 & 0.093 & 0.863 & 0.044 \\
\hline
\end{tabular}

$\mathrm{n}$ : number of subjects. 
TABLE 2

Frequencies (\%) of CYP2C9 alleles and phenotypes predicted from genotype in different Costa Rican ethnic groups

\begin{tabular}{lcccccc}
\multicolumn{1}{c}{ Self-reported Ancestry } & $\mathrm{n}$ & $* 1$ & $* 2$ & $* 3$ & $* 6$ & gPMs \\
Admixed & 137 & 88.7 & 7.7 & 3.6 & 0.0 & 0.7 \\
Bribri & 46 & 97.8 & $1.1^{\mathrm{a}}$ & 1.1 & 0.0 & 0.0 \\
Cabécar & 27 & 98.1 & $0.0^{\mathrm{a}}$ & 1.9 & 0.0 & 0.0 \\
Chorotega & 31 & 95.1 & 3.2 & 1.6 & 0.0 & 0.0 \\
Guaymí & 27 & 100.0 & $0.0^{\mathrm{a}}$ & 0.0 & 0.0 & 0.0 \\
Huetar & 48 & 86.5 & 8.3 & 5.2 & 0.0 & 0.0 \\
Maleku & 15 & 100.0 & 0.0 & 0.0 & 0.0 & 0.0 \\
Afro-Caribbean & 45 & 95.6 & $1.1^{\mathrm{a}}$ & 3.3 & 0.0 & 0.0 \\
\hline
\end{tabular}

$\mathrm{n}$ : number of subjects; gPMs: predicted poor metabolizers from genotype.

${ }^{\text {ap }}<0.05$ compared to the admixed and Huetar populations.

TABLE 3

Frequencies (\%) of CYP2C19 alleles and phenotypes predicted from genotype in different Costa Rican ethnic groups

\begin{tabular}{lccccccccc} 
Self-reported Ancestry & $\mathrm{n}$ & $* 1$ & $* 2$ & $* 3$ & $* 4$ & $* 5$ & $* 17$ & gPMs & gUMs \\
Admixed & 141 & 81.9 & 7.1 & 0.0 & 0.7 & 0.0 & 10.3 & 0.0 & 17.7 \\
Bribri & 23 & 91.3 & 4.3 & 0.0 & 0.0 & 0.0 & 4.3 & 0.0 & 8.7 \\
Chorotega & 36 & 84.7 & 12.5 & 0.0 & 0.0 & 0.0 & 2.8 & 0.0 & 5.6 \\
Guaymí & 24 & 98.0 & 0.0 & 0.0 & 0.0 & 0.0 & 2.0 & 0.0 & 4.0 \\
Maleku & 12 & 100.0 & 0.0 & 0.0 & 0.0 & 0.0 & 0.0 & 0.0 & 0.0 \\
Afro-Caribbean & 46 & 58.7 & $19.6^{\mathrm{a}}$ & 0.0 & 0.0 & 0.0 & $21.7^{\mathrm{b}}$ & 0.0 & $32.6^{\mathrm{b}}$ \\
\hline
\end{tabular}

n: number of subjects; gPMs: predicted poor metabolizers from genotype; gUMs: predicted ultra-rapid metabolizers from genotype.

${ }^{a} \mathrm{P}<0.05$ compared to the rest of populations with the exception of the Chorotega tribe; ${ }^{\mathrm{b}} \mathrm{P}<0.05$ compared to the rest of populations.

103 previously proposed (Yaeger et al., 2008) were genotyped to infer African, European and Native American ancestry at individual and population levels. The SequenomiPLEX platform (San Diego, CA, USA) genotyping (Pereira et al., 2012) was performed at the Centro Nacional de Genotipado (CEGEN, Santiago de Compostela, Spain). In the analyses, data from 119 Yoruba unrelated individuals from Ibadan, Nigeria (YRI) and 60 Utah residents with European ancestry from the CEPH collection (CEU) from The International HapMap Consortium (2010) were included as parental populations. The Expectation Maximization method implemented in the software Admixture (Alexander, Novembre, \& Lange, 2009) was used to estimate ancestry, assuming three parental populations $(\mathrm{k}=3)$.
CYP2C9 and CYP2C19 genotyping: Genotyping for the $C Y P 2 C 9 * 2$ (rs1799853), *3 (rs1057910), *6 (rs9332131) and CYP2C19*2 (rs4244285), *3 (rs4986893), *4 (rs28399504), *5 (rs28399504) and *17 (rs12248560) alleles was carried out on genomic DNA using TaqMan assays as previously described (Dorado et al., 2012b; Llerena et al., 2014a; PeñasLledó et al., 2014). Chromosomes lacking the above-mentioned alleles/SNPs were classified as $C Y P 2 C 9^{*} 1$ and $C Y P 2 C 19^{*} 1$.

CYP2D6 genotyping: Data on CYP2D6*2 (rs1080985), *3 (rs35742686), *4 (rs1065852, rs3892097), *6 (rs5030655), *10 (rs1065852), *17 (rs28371706), *29 (rs59421388), *35 (rs1080985 and rs769258), *41 (rs28371725), $C Y P 2 D 6 * 5, C Y P 2 D 6 * 1 x N, * 2 x N, * 4 x N$ and 
$* 10 x N$ alleles were published for the Costa Rican population (Céspedes-Garro et al., 2014a; Céspedes-Garro et al., 2014b).

Predicted hydroxylation capacity group: To infer metabolic phenotype from the genotypes, zero value was assigned to $C Y P 2 C 9 * 3$ and $* 6$ and $C Y P 2 C 19 * 2, * 3, * 4$ and $* 5$ variants, 0.5 value to $C Y P 2 C 9 * 2$, one to $C Y P 2 C 9 / 19 * 1$, and two to $C Y P 2 C 19 * 17$ (Peñas-Lledó et al., 2014). Individuals with activity score values equal to zero were classified as gPMs, and individuals with activity score higher than two were classified as gUMs (for CYP2C19) (Peñas-Lledó et al., 2014). An activity score was adapted for CYP2D6 (Gaedigk et al., 2008; Llerena et al., 2012). Previously reported data on CYP2D6 have been analyzed together with original ancestry information of the subjects.

The differences in CYP2C9 and CYP2C19 allele frequencies among populations were compared using the Fisher's exact test (alpha = 0.05). Hardy-Weinberg equilibrium for alleles was determined using a contingency table $\mathrm{X}^{2}$ statistic with Yate's correction. Statistical analyses were performed using the STATISTICA 4.3 (StatSoft, Tulsa, OK, USA) and GraphPad Prism 3.02 (GraphPad Software, San Diego, CA, USA).

The correlation between individual ancestry and the number of copies of a specific allele in each individual was estimated using the Spearman's rank correlation, with the R cor.test command (R Foundation, 2015).

\section{RESULTS}

Genomic ancestry: The studied individuals and populations from Costa Rica encompass a wide spectrum of continental ancestry and self-reported admixed individuals from the Central Valley and Guanacaste showed many of the possible combinations of European, African and Native American admixture (Fig. 1). Moreover, the three self-reported

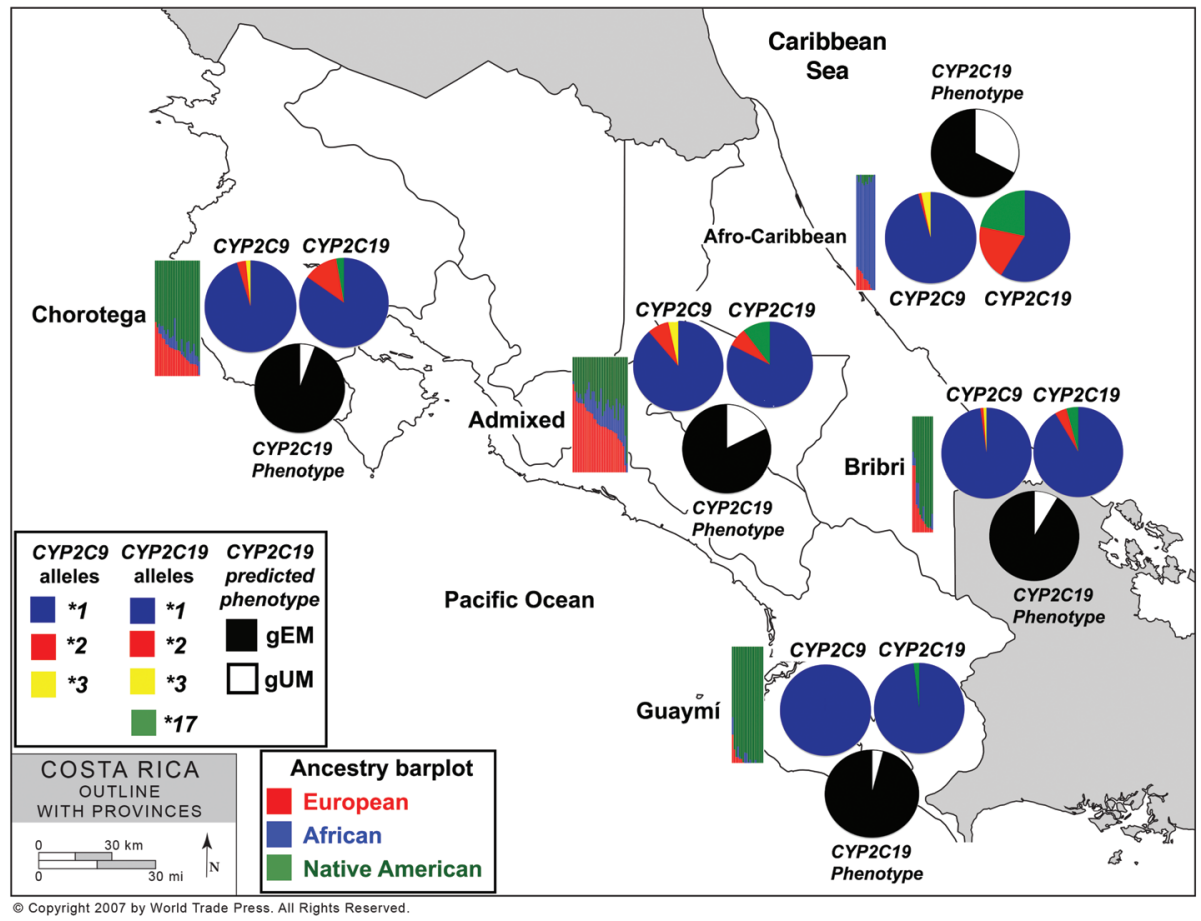

Fig. 1. Barplots of individual continental ancestry, main $C Y P 2 C 9$ and $C Y P 2 C 19$ alleles and CYP2C19 predicted phenotypes frequency distributions in Costa Rican populations. The approximate location of populations is shown in the chart. 
Native groups mostly have Native American ancestry, with low African ancestry $(<9 \%)$ and European ancestry that range from $3 \%$ (in Guaymí) to $22 \%$ in the Chorotega. The AfroCaribbean population has a very high African ancestry (86\%), with all the individuals showing more than $76 \%$ of African ancestry (Table 1 and Fig. 1).

CYP2C9 and CYP2C19 alleles and predicted metabolic phenotypes: $C Y P 2 C 9$ and $C Y P 2 C 19$ genotype frequencies fit the Hardy-Weinberg equilibrium for all the studied populations.

Consistently with previous studies, the wild-type $C Y P 2 C 9^{*} 1$ is modal in all populations (Table 2). The decreased-activity $C Y P 2 C 9 * 2$ allele frequency was higher in the Admixed and Huetar populations (7-8 \%) than in the Afro-Caribbean, Bribri, Cabécar, Maleku and Guaymí $(<1.1 \%$; $\mathrm{P}<0.05)$. No differences were found in the frequency of the decreasedactivity $C Y P 2 C 9 * 3$ allele across the different groups. The null-activity $C Y P 2 C 9 * 6$ variant was not detected in the Costa Rican populations. Moreover, only one admixed subject was a CYP2C9 predicted poor metabolizer (gPMs).

For CYP2C19, both the null-activity $C Y P 2 C 19 * 2$ allele and the increased-activity $C Y P 2 C 19 * 17$ allele were more common in the Afro-Caribbean population than in the other Costa Rican groups $(\mathrm{P}<0.05)$ (Table 3$)$. These allele distributions suggest that almost a third of the subjects in the Afro-Caribbean population (15 out of 46) are gUMs for CYP2C19, more than in any other Costa Rican group $(\mathrm{P}<0.05)$.

The null-activity $C Y P 2 C 19 * 3$ and $C Y P 2 C 19 * 5$ alleles were not present in any of the studied populations, and CYP2C19*4 was only present in heterozygosis in two subjects of the admixed population. No CYP2C19 gPMs were found in the entire Costa Rican sample.

Relationship between $C Y P 2$ genes and genomic ancestry: For Costa Rica, a correlation between Native American and African ancestry with $C Y P 2 C 19$ and $C Y P 2 D 6$ variant alleles was found. The following alleles were positively correlated with African ancestry and negatively correlated with Native American ancestry: CYP2D6*5 $(\mathrm{P}<0.01), C Y P 2 D 6^{*} 17$ $(\mathrm{P}<0.01), C Y P 2 D 6^{*} 29 \quad(\mathrm{P}=0.027$ for African and $\mathrm{P}=0.045$ for Native American) and CYP 2 C19*17 $(\mathrm{P}<0.01)$. We found no correlation for $C Y P 2 C 9$ polymorphisms and ancestry.

\section{DISCUSSION}

This is the first study on CYP2C9 and CYP2C19 in a multiethnic Costa Rican population, and it has been contextualized estimating the genomic ancestry of these populations.

The observed low frequency of the decreased-activity allele $C Y P 2 C 9 * 2$ in the most Amerindian populations from Costa Rica (Bribri, Cabécar, Maleku and Guaymí) (Azofeifa, Ruiz, \& Barrantes, 2001), is consistent with other studies on North- and South- Amerindians, which reported frequencies from 0 to $4.8 \%$ for this allele (Céspedes-Garro et al., 2015). Noteworthy, the high $C Y P 2 C 9 * 2$ frequency in the Huetar $(8.3 \%)$ is similar to that of the Costa Rican admixed population (7.7\%), in agreement with reports that estimate that the Huetar groups have European and African admixture as high as 3.9 to $32.9 \%$ (Barrantes, 1993; Santos, Ward, \& Barrantes, 1994; Bieber, Bieber, Rodewald, \& Barrantes, 1996; Azofeifa et al., 2001; Ruiz-Narváez et al., 2005).

The frequency of $C Y P 2 C 9 * 2$ for the admixed Costa Rican population is similar to those reported for other Latin American admixed populations from Brazil, Chile, Ecuador, Mexico and Hispanics from United States of America (Céspedes-Garro et al., 2015).

The very low frequencies of CYP2C9 gPMs in the Costa Rican populations (predicted by surveying the presence of the $* 3$ and $* 6$ allele), is also in agreement with other studies in diverse Latin American and Native American populations, including US-Hispanics (Céspedes-Garro et al., 2015). This frequency can indicate that Costa Rican populations are not susceptible to adverse reactions of CYP2C9metabolized drugs (warfarin, losartan, diclofenac) due to genetic factors. 
Regarding CYP2C19 in Native Costa Ricans, the frequency of the null-activity allele CYP2C19*2 varies from 0 to $12.5 \%$. The $C Y P 2 C 19 * 2$ frequency in the Chorotega tribe $(12.5 \%)$ was similar to that reported for Ameridian populations from Brazil (10.4 and 11.1 \%) (Santos et al., 2011; Vargens, Petzl-Erler, \& Suarez-Kurtz, 2012). The low frequencies for this allele in Bribri, Maleku and Guaymí populations (4.3, 0 and $0 \%$, respectively) are similar to those from the Purépechas, Tzotziles, Tojolabales and Tzeltales Mexican Amerindian tribes (5.4, 5.6, 3.6 and $0 \%$, respectively) (Salazar-Flores et al., 2012).

As previously reported, $C Y P 2 C 19 * 3$ frequency is rare outside Eastern Asia and Melanesia (Sistonen et al., 2009); for this reason, the lack of this allele in Costa Rican populations was expected.

The increased-activity $C Y P 2 C 19 * 17$ allele frequency of the Afro-Caribbean population is consistent with its high frequency in the West African Gambia population (23.0 \%) (Janha et al., 2014), which is in accordance to the predominant Western African origin of the African diaspora to the Americas (Madrigal, 2006). The ascertainment of CYP2C19 gUMs by genotyping of the CYP2C19*17 allele has only been performed in other two Latin American admixed populations from Brazil and Ecuador (26.8 and $41.4 \%$, respectively) (Santos et al., 2011; Vicente et al., 2014), and both frequencies are higher than that of the Costa Rican admixed population (17.7\%; $\mathrm{P}<0.05)$. This result suggest that Costa Rican populations are less susceptible to therapeutic failure or adverse reactions in therapies based on drugs metabolized by CYP2C19, such as omeprazole and clopidogrel.

A correlation among CYP2D $6 * 5, * 17$ and $* 29$ alleles with ancestry was also found in this study, consistently with higher frequencies of $* 17$ and $* 29$ in African populations (Llerena et al., 2014b). The null-activity $C Y P 2 D 6^{*} 4$ allele is associated to European ancestry (Llerena et al., 2014b), and is supposed to be a marker of this ancestry. However, in our multiethnic sample of individuals, the CYP2D6*4 allele is also present in 23 individuals with more than $30 \%$ of Native American ancestry and less than 60 $\%$ of European ancestry. Furthermore, the highest frequencies of CYP $2 D 6^{*} 4$ worldwide are in the Chibchan groups (e.g. Bari from Venezuela - $42.5 \%$ - and Bribri and Cabécar from Costa Rica - 31.9 and $26.8 \%$, respectively) (Céspedes-Garro et al., 2014a; Céspedes-Garro et al., 2014b). Altogether, our results suggest that the *4 allele may be also common in Native American populations.

A limitation of this study is the low number of individuals in some of the populations, mainly Amerindians. However, considering that Amerindians are under-represented in pharmacogenetics surveys, important information is provided. Another limitation, shared with most pharmacogenetics studies, is that we genotyped specific SNPs that define specific alleles (haplotypes) and classified as wild type $\left(C Y P 2 C 9^{*} 1\right.$ or $\left.C Y P 2 C 19 * 1\right)$ the individuals that do not carry these alleles. However, it is unknown if populations that are underrepresented in pharmacogenetics studies, such as Native Americans, may present variants that were not genotyped, or that were even unknown and that may alter enzymatic activity. Thus, further studies assessing the CYP2C 9 and $C Y P 2 C 19$ sequence in an unbiased fashion, preferentially by sequencing these genes, would be necessary.

\section{ACKNOWLEDGMENTS}

CCG was supported by a fellowship of the University of Costa Rica in the $\mathrm{PhD}$ program of the University of Extremadura. The study is part of the Research Program entitled "Genética, Ecología y Salud en los Amerindios de Costa Rica" (N $\left.{ }^{\circ} 742-93-903\right)$ and the project $\mathrm{N}^{\circ} 742-90-416$ of the University of Costa Rica. The research was supported by a grant from Junta de Extremadura, Cooperación Extremeña AEXCID 13IA001. ET-S and FRS were supported by the CAPES Agency of the Brazilian Ministry of Education. The project was coordinated in the CEIBA.FP Consortium of the 
Ibero-American Network of Pharmacogenetics \& Pharmacogenomics (RIBEF).

\section{RESUMEN}

Relevancia de la ancestría para la variabilidad de polimorfismos de las enzimas metabolizadoras de fármacos CYP2C9, CYP2C19 y CYP2D6 en una población multiétnica de Costa Rica. CYP2C9, CYP2C19 y CYP2D6 metabolizan aproximadamente el $40 \%$ de los fármacos y los genes que las codifican varían en las distintas poblaciones humanas. La población costarricense posee ancestría trihíbrida y su posición geográfica estratégica la convierten en un escenario idóneo para evaluar la variabilidad interétnica en sus poblaciones multiétnicas. El presente estudio tiene como objetivo describir la diversidad de los polimorfismos CYP2C9, CYP2C19 y CYP2D6 en las poblaciones costarricenses en el contexto de su ancestría. Un total de 448 individuos sanos fueron incluidos: Bribri $(n=47)$, Cabécar $(n=27)$, Maleku ( $n=16)$, Guaymí $(n=30)$, Huetar $(n=48)$, Chorotega $(n=41)$, mestizos del Valle Central y Guanacaste $(n=189)$ y afrocaribeños de Limón $(n=$ 50). Los genotipos CYP2C9 (alelos *2, *3, *6) y CYP2C19 $(* 2, * 3, * 4, * 5 \mathrm{y} * 17)$ fueron determinados mediante PCR tiempo real. Las ancestrías africana, europea y nativa americana fueron inferidas usando 87 marcadores informativos de ancestría. La frecuencia del alelo de actividad disminuida $C Y P 2 C 9 * 2$ fue menor en los grupos autodefinidos de amerindios que en la población mestiza y las frecuencias más altas de $C Y P 2 C 19 * 2$ (actividad nula) y $C Y P 2 C 19 * 17$ (actividad incrementada) se encontraron en la población autodefinida afrocaribeña. Asimismo, se encontró una frecuencia de gPMs CYP2C9 de $0.7 \%$ en la población mestiza y una frecuencia variable de gUMs CYP2C19 ( 0.0 a $32.6 \%$, más prevalente en afrocaribeños) en las poblaciones costarricenses. Por último, los siguientes alelos fueron positivamente correlacionados con la ancestría africana y negativamente con la ancestría nativa americana: CYP2D6*5 (actividad nula), CYP2D6*17, CYP2D6*29 (ambos de actividad disminuida) y CYP2C19*17 (actividad incrementada). No se encontró correlación entre los polimorfismos CYP2C9 y la ancestría. Se requieren estudios posteriores que evalúen la secuencia de $C Y P 2 C 9$ y CYP2C19 en estas poblaciones, preferiblemente mediante la secuenciación de estos genes.

Palabras clave: $C Y P 2 C 9, C Y P 2 C 19, C Y P 2 D 6$, Costa Rica, amerindios, afrocaribeños, ancestría genética.

\section{REFERENCES}

Alexander, D. H., Novembre, J., \& Lange, K. (2009). Fast model-based estimation of ancestry in unrelated individuals. Genome Research, 19(9), 1655-1664.
Altar, C. A., Carhart, J. M., Allen, J. D., Hall-Flavin, D. K., Dechairo, B. M., \& Winner, J. G. (2015). Clinical validity: Combinatorial pharmacogenomics predicts antidepressant responses and healthcare utilizations better than single gene phenotypes. The Pharmacogenomics Journal, 15(5), 443-451.

Azofeifa, J., Hahn, M., Ruiz, E., Hummerich, L., Morales, A. I., Jiménez, G., \& Barrantes, R. (2004). The STR polymorphism (AAAAT)n within the intron 1 of the tumor protein 53 (TP53) locus in 17 populations of different ethnic groups of Africa, America, Asia and Europe. Revista de Biologia Tropical, 52(3), 645-657.

Azofeifa, J., Ruiz, E., \& Barrantes, R. (2001). Blood group, red cell, and serum protein variation in the Cabécar and Huetar, two Chibchan Amerindian tribes of Costa Rica. American Journal of Human Biology: The Official Journal of the Human Biology Council, 13(1), 57-64.

Barrantes, R. (1993). Diversidad genética y mezcla racial en los amerindios de Costa Rica y Panamá. Revista de Biologia Tropical, 41(3 A), 379-384.

Barrantes, R., Smouse, P. E., Mohrenweiser, H. W., Gershowitz, H., Azofeifa, J., Arias, T. D., \& Neel, J. V. (1990). Microevolution in lower Central America: genetic characterization of the Chibcha-speaking groups of Costa Rica and Panama, and a consensus taxonomy based on genetic and linguistic affinity. American Journal of Human Genetics, 46(1), 63-84.

Barrantes, R., Smouse, P. E., Neel, J. V., Mohrenweiser, H. W., \& Gershowitz, H. (1982). Migration and genetic infrastructure of the central American Guaymí and their affinities with other tribal groups. American Journal of Physical Anthropology, 58(2), 201-214.

Bieber, H., Bieber, S. W., Rodewald, A., \& Barrantes, R. (1996). Microevolution and genetic affinities among six Amerindian tribes of lower Central America: comparative genetic study of serum proteins. Human Biology, 68(6), 929-953.

Center for Drug Evaluation and Research. (2015). Genomics - Table of Pharmacogenomic Biomarkers in Drug Labeling. Retrieved from http:/www.fda.gov/ drugs/scienceresearch/researchareas/pharmacogenetics/ucm083378.htm

Céspedes-Garro, C., Fricke-Galindo, I., Naranjo, M. E. G., Rodrigues-Soares, F., Fariñas, H., de Andrés, F., López-López, M., Peñas-Lledó, E. M., \& Llerena, A. (2015). Worldwide interethnic variability and geographical distribution of CYP2C9 genotypes and phenotypes. Expert Opinion on Drug Metabolism \& Toxicology, 11(12), 1-13.

Céspedes-Garro, C., Jiménez-Arce, G., Naranjo, M. E. G., Barrantes, R., \& Llerena, A. (2014a). Ethnic background and CYP2D6 genetic polymorphisms in Costa Ricans. Revista de Biología Tropical, 62(4), 1659-1671. 
Céspedes-Garro, C., Naranjo, M. E. G., Ramírez, R., Serrano, V., Fariñas, H., Barrantes, R., \& Llerena, A. (2014b). Pharmacogenetics in Central American healthy volunteers: interethnic variability. Drug Metabolism and Personalized Therapy, 30(1), 19-31.

CYP2C19 allele nomenclature. (2015). Retrieved from http://www.cypalleles.ki.se/cyp2c19.htm

CYP2C9 allele nomenclature. (2015). Retrieved from http://www.cypalleles.ki.se/cyp2c9.htm

CYP2D6 allele nomenclature. (2015). Retrieved June from http://www.cypalleles.ki.se/cyp2d6.htm

Dorado, P., Beltrán, L. J., Machín, E., Peñas-Lledó, E. M., Terán, E., \& Llerena, A. (2012a). Losartan hydroxylation phenotype in an Ecuadorian population: influence of CYP2C9 genetic polymorphism, habits and gender. Pharmacogenomics, 13(15), 1711-1717.

Dorado, P., Gallego, A., Peñas-Lledó, E., Terán, E., \& Llerena, A. (2014). Relationship between the CYP2C9 IVS8-109A $>$ T polymorphism and high losartan hydroxylation in healthy Ecuadorian volunteers. Pharmacogenomics, 15(11), 1417-1421.

Dorado, P., Machín, E., De Andrés, F., Naranjo, M. E. G., Peñas-Lledó, E. M., \& Llerena, A. (2012b). Development of a HPLC method for the determination of losartan urinary metabolic ratio to be used for the determination of CYP2C9 hydroxylation phenotypes. Drug Metabolism and Drug Interactions, 27(4), 217-223.

Gaedigk, A., Simon, S. D., Pearce, R. E., Bradford, L. D., Kennedy, M. J., \& Leeder, J. S. (2008). The CYP2D6 activity score: translating genotype information into a qualitative measure of phenotype. Clinical Pharmacology and Therapeutics, 83(2), 234-242.

Ingelman-Sundberg, M., Sim, S. C., Gómez, A., \& Rodríguez-Antona, C. (2007). Influence of cytochrome P450 polymorphisms on drug therapies: pharmacogenetic, pharmacoepigenetic and clinical aspects. Pharmacology \& Therapeutics, 116(3), 496-526.

Janha, R. E., Worwui, A., Linton, K. J., Shaheen, S. O., Sisay-Joof, F., \& Walton, R. T. (2014). Inactive alleles of cytochrome P450 2C19 may be positively selected in human evolution. BMC Evolutionary Biology, 14, 71 .

Llerena, A., Álvarez, M., Dorado, P., González, I., PeñasLledó, E., Pérez, B., Cobaleda, J., \& Calzadilla, L. R. (2014a). Interethnic differences in the relevance of CYP2C9 genotype and environmental factors for diclofenac metabolism in Hispanics from Cuba and Spain. The Pharmacogenomics Journal, 14(3), 229-234.

Llerena, A., Dorado, P., Ramírez, R., González, I., Álvarez, M., Peñas-Lledó, E. M., Pérez, B., \& Calzadilla, L. R. (2012). CYP2D6 genotype and debrisoquine hydroxylation phenotype in Cubans and Nicaraguans. The Pharmacogenomics Journal, 12(2), 176-183.

Llerena, A., Naranjo, M. E. G., Rodrigues-Soares, F., Penas-Lledó, E. M., Fariñas, H., \& Tarazona-Santos, E. (2014b). Interethnic variability of CYP2D6 alleles and of predicted and measured metabolic phenotypes across world populations. Expert Opinion on Drug Metabolism \& Toxicology, 10(11), 1569-1583.

Madrigal, L. (2006). Human biology of Afro-Caribbean populations. Cambridge studies in biological and evolutionary anthropology. New York, USA: Cambridge University Press.

Niu, X., Mao, L., Huang, Y., Baral, S., Li, J. Y., Gao, Y., Xia, Y. P., He, Q. W., Wang, M. D., Li, M., Zou, L., Miao, X. P., \& Hu, B. (2015). CYP2C19 polymorphism and clinical outcomes among patients of different races treated with clopidogrel: A systematic review and meta-analysis. Journal of Huazhong University of Science and Technology. Medical Sciences = Hua Zhong Ke Ji Da Xue Xue Bao. Yi Xue Ying De Wen Ban = Huazhong Keji Daxue Xuebao. Yixue Yingdewen Ban, 35(2), 147-156.

Peñas-Lledó, E., Guillaume, S., Naranjo, M. E. G., Delgado, A., Jaussent, I., Blasco-Fontecilla, H., Courtet, P., \& Llerena, A. (2014). A combined high CYP2D6CYP2C19 metabolic capacity is associated with the severity of suicide attempt as measured by objective circumstances. The Pharmacogenomics Journal, 15(2), 172-176.

Pereira, L., Zamudio, R., Soares-Souza, G., Herrera, P., Cabrera, L., Hooper, C. C., Cok, J., Combe, J. M., Vargas, G., Prado, W. A., Schneider, S., Kehdy, F., Rodrigues, M. R., Chanock, S. J., Berg, D. E., Gilman, R. H., \& Tarazona-Santos, E. (2012). Socioeconomic and nutritional factors account for the association of gastric cancer with Amerindian ancestry in a Latin American admixed population. PloS One, 7(8), e41200.

R Foundation. (2015). R: The R Project for Statistical Computing. Retrieved from http://www.r-project.org/

Rolla, R., Gramaglia, C., Dalò, V., Ressico, F., Prosperini, P., Vidali, M., Meola, S., Pollarolo, P., Bellomo, G., Torre, E., \& Zeppegno, P. (2014). An observational study of Venlafaxine and CYP2D6 in clinical practice. Clinical Laboratory, 60(2), 225-231.

Ruiz-Narváez, E. A., Santos, F. R., Carvalho-Silva, D. R., Azofeifa, J., Barrantes, R., \& Pena, S. D. J. (2005). Genetic variation of the Y chromosome in Chibchaspeaking Amerindians of Costa Rica and Panama. Human Biology, 77(1), 71-91.

Salazar-Flores, J., Torres-Reyes, L. A., Martínez-Cortés, G., Rubi-Castellanos, R., Sosa-Macías, M., MuñozValle, J. F., González-González, C., Ramírez, A., Román, R., Méndez, J. L., Barrera, A., Torres, A., Medina, R., \& Rangel-Villalobos, H. (2012). 
Distribution of CYP2D6 and CYP2C19 polymorphisms associated with poor metabolizer phenotype in five Amerindian groups and western Mestizos from Mexico. Genetic Testing and Molecular Biomarkers, 16(9), 1098-1104.

Santos, M., Ward, R. H., \& Barrantes, R. (1994). mtDNA variation in the Chibcha Amerindian Huetar from Costa Rica. Human Biology, 66(6), 963-977.

Santos, P. C. J. L., Soares, R. A. G., Santos, D. B. G., Nascimento, R. M., Coelho, G. L. L. M., Nicolau, J. C., Mill, J. G., Krieger, J. E., \& Pereira, A. C. (2011). CYP2C19 and ABCB1 gene polymorphisms are differently distributed according to ethnicity in the Brazilian general population. BMC Medical Genetics, 12, 13.

Segura-Wang, M., Raventós, H., Escamilla, M., \& Barrantes, R. (2010). Assessment of genetic ancestry and population substructure in Costa Rica by analysis of individuals with a familial history of mental disorder. Annals of Human Genetics, 74(6), 516-524.

Seripa, D., Latina, P., Fontana, A., Gravina, C., Lattanzi, M., Savino, M., Gallo, A. P., Melchionda, G., Santini, S. A., Margaglione, M., Copetti, M., di Mauro, L., Panza, F., Greco, A., \& Pilotto, A. (2015). Role of CYP2D6 polymorphisms in the outcome of postoperative pain treatment. Pain Medicine, 16(10), 2012-2023.

Sistonen, J., Fuselli, S., Palo, J. U., Chauhan, N., Padh, H., \& Sajantila, A. (2009). Pharmacogenetic variation at CYP2C9, CYP2C19, and CYP2D6 at global and microgeographic scales. Pharmacogenetics and Genomics, 19(2), 170-179.

Sosa-Macias, M., Moya, G. E., Llerena, A., Ramírez, R., Terán, E., Peñas-Lledó, E. M., Tarazona-Santos, E., Galaviz-Hernández, C., Céspedes-Garro, C., \& Acosta, H. (2015). Population pharmacogenetics of Ibero-Latinoamerican populations (MESTIFAR 2014). Pharmacogenomics, 16(7), 673-676.

Tabata, N., Hokimoto, S., Akasaka, T., Arima, Y., Sakamoto, K., Yamamoto, E., Tsujita, K., Izumiya, Y.,Yamamuro, M., Kojima, S., Kaikita, K., Kumagae, N., Morita, K., Oniki, K., Nakagawa, K., Matsui, K.,
\& Ogawa, H. (2015). Patients with both CYP2C19 loss-of-function allele and peripheral endothelial dysfunction are significantly correlated with adverse cardiovascular events following coronary stent implantation. Journal of Cardiology, 67(1), 104-109.

The International HapMap Consortium. (2010). Integrating common and rare genetic variation in diverse human populations. Nature, 467(7311), 52-58.

Vargens, D. D., Petzl-Erler, M. L., \& Suarez-Kurtz, G. (2012). Distribution of CYP2C polymorphisms in an Amerindian population of Brazil. Basic \& Clinical Pharmacology \& Toxicology, 110(4), 396-400.

Vicente, J., González-Andrade, F., Soriano, A., Fanlo, A., Martínez-Jarreta, B., \& Sinués, B. (2014). Genetic polymorphisms of CYP2C8, CYP2C9 and CYP2C19 in Ecuadorian Mestizo and Spaniard populations: a comparative study. Molecular Biology Reports, 41(3), 1267-1272.

Yaeger, R., Avila-Bront, A., Abdul, K., Nolan, P. C., Grann, V. R., Birchette, M. G., Choudhry, S., Burchard, E. G., Beckman, K. B., Gorroochurn, P., Ziv, E., Consedine, N. S., \& Joe, A. K. (2008). Comparing genetic ancestry and self-described race in african americans born in the United States and in Africa. Cancer Epidemiology, Biomarkers \& Prevention: A Publication of the American Association for Cancer Research, Cosponsored by the American Society of Preventive Oncology, 17(6), 1329-1338.

Yang, J., Chen, Y., Li, X., Wei, X., Chen, X., Zhang, L., Zhang, Y., Xu, Q., Wang, H., Li, Y., Lu, C., Chen, W., Zeng, C., \& Yin, T. (2013). Influence of CYP2C9 and VKORC1 genotypes on the risk of hemorrhagic complications in warfarin-treated patients: a systematic review and meta-analysis. International Journal of Cardiology, 168(4), 4234-4243.

Youngster, I., Zachor, D. A., Gabis, L. V., Bar-Chaim, A., Benveniste-Levkovitz, P., Britzi, M., Soback, S., Ziv-Baran, T., \& Berkovitch, M. (2014). CYP2D6 genotyping in paediatric patients with autism treated with risperidone: a preliminary cohort study. Developmental Medicine and Child Neurology, 56(10), 990-994. 